\section{US universities}

\section{All change at St Louis}

St Louis, Missouri

THE Washington University, part of this city's pride (after the arch across the Mississippi and its baseball team, the Cardinals), is part way through an administrative revolution that keeps many of the faculty awake at nights. Two years ago, the trustees decreed that the School of Arts and Sciences should follow the professional schools into financial and administrative autonomy. One result could be that academic departments less able to fend for themselves financially - philosophy but even physics - might go out of business.

The School of Arts and Sciences has had autonomy thrust upon it. Two years ago, it was the only school of the university not paddling its own canoe. The argument for change starts from the observation that other schools that have been independent for some time (medicine conspicuously) have prospered, partly from the ease of making deals with outside backers and partly by commanding the loyalty of their alumni. But then, as the administrators are fond of saying, is this not what the Harvards of this world do?

Under the arrangement, called "being put on reserve" in reference to the share of the whole endowment that autonomy commands, a school is the fiefdom of its dean. Policy on admissions, curriculum and even salary levels is determined separately. Now, in the School of Arts and Sciences, tuition fees (in excess of $\$ 8,000$ a year for undergraduates) go into a pool with other income, but the school pays a levy to support central activities.

Worries among the faculty take several forms. The philosophy and classics departments (large and small respectively) may not be financially viable, but can a university claim the name without offering courses in such fields? But even physicists fear that the engineering school, which now pays a fee to arts and sciences for service physics teaching, may decide to teach its own physics as an economy. (The chancellor, Dr John Danworth, says the service fee, fixed by the trustees, could not be changed without their consent.) Then there is the general worry that autonomy will turn all academics into fund-raisers, or that only successful fund-raiders will prosper.

The chancellor is anxious that autonomy should work, but is for the time being openminded about the change. If it does not bring the benefits intended, the trustees would think again. And a successor might wish to see the omelette unscrambled. But in Danworth's view, only autonomy can make a faculty responsible for its academic future. He cites his own earlier success, as head of the medical division, in turning a bankrupt dental school into a successful enterprise with the help of a tapering subvention from the centre $(\$ 600,000$ over three years) coupled with the threat that failure would spell closure.

In any case, Danworth says, it is no longer possible for the head of a private university, forever occupied with fundraising and negotiations with government agencies, to be so involved with academic life as to provide single-handed academic leadership. This leads him, after careful thought, to an unyieldng position on the issue of the weaker departments; if the faculty of arts and sciences should think of closing one of them, the whole value of independence would be lost if he or the trustees should intervene to halt the closure. But what a chancellor can do is to fire a dean who has failed to carry the faculty with his decisions. Danworth is said to read faculty meeting minutes like a hawk.

Ultimately, the success of the experiment will hang on whether arts and science can raise the funds needed to stay alive, and on whether the faculty is sufficiently committed to the ideal of a liberal education for the well-to-do to indulge their less commercially viable colleagues.

That money is so dominating surprises nobody at St Louis, although most academics are more concerned with the competition for high-quality students, which they say is a prerequisite for commercial success. They point to rising scores in the national college boards examinations and a widening catchment area (with only 20 per cent of undergraduates from the locality). Physics has now followed engineering in offering a handful of undergraduate scholarships, saying that even students who compete unsuccessfully for them leave their applications in. The faculty also claims that other universities are prevented by the egalitarian climate

from following this elitist course.

So far, the university has been lucky in its donors. The chemical company Monsanto, only one of the reasons why East St Louis (across the river in Illinois) is such a slum, made a 5-year grant of \$27 million to the medical school two years ago, from which non-medical biologists also profit. McDonnell Douglas, the aircraft manufacturer, has been generous over several years, partly because of the interest of the late founder of the company (known generally as "Mr Mac") in space research (whence the flexibly endowed McDonnell Center for Space Research) and in parapsychology (engendering less pride). By contrast, General Dynamics, also based in St Louis and now in trouble for misdemeanours such as lodging a senior manager's dog in a commercial kennel at the Pentagon's expense, is almost conspicuous for the modesty of its support.

As a research university, Washington dates its rise to the post-war chancellorship of A.H. Compton, who arrived at St Louis in 1945 with a group from Los Alamos. More recently, the medical school has made the running.

For a big-city urban university, Washington is suprisingly well-provided. It is compact (mostly on one campus, with the medical school two miles downtown) and hemmed in by amenities such as Forest Park, the site of the world's fair in 1904 which persuaded the rest of the United States that St Louis is not some outlying suburb of Chicago (more than 300 miles away). The setting is also a physical constraint on growth, but nobody wants that any more. The snag is that even successful departments may be smaller than a critical intellectual mass which is why, whatever the consequences of autonomy for arts and sciences, a measure of concentration may be prudent.

John Maddox

\title{
European geoscience union thrives
}

THE European Union of Geosciences (EUG), at its third meeting in Strasbourg on 1-4 April, appears to have established itself. Since EUG's foundation five years ago under C.J. Allègre of the University of Paris, attendance at the biennial meetings has increased from 600 in 1981 to more than 1,500 this year. The annual spring and fall meetings of the American Geophysical Union attract between 2,000 and 2,500 participants.

The need for such a forum in Europe was one of the stimuli for the creation of EUG, says the new president, Professor E.R.Oxburgh (University of Cambridge). There is a particular need, he says, for European earth science research students to meet and to present their work to more established people. To this end, costs are kept as low as possible. This year, more than 200 travel grants, valued at $\mathbf{1 1 0 , 0 0 0}$, were awarded for the meeting. In his presidential address, H.Wänke (Max
Planck Institute, Mainz) said that he knew of no comparable organization that spends so much of its income in this way.

EUG works on the principle that membership is strictly individual. Other than a part-time secretary provided by the European Science Foundation, the union has no permanent administration. Allègre says that EUG is essentially antibureaucratic.

Meetings are organized in turn by members from one country. The 1985 meeting was arranged primarily by the University of Cambridge, and the next(in 1987) will be organized by Eidgenossische Technische Hochschule, Zurich. After that, Italy will probably take over. All the meetings will take place in Strasbourg. Although some officers feel that this rotation of responsibility is a strength, others fear that growth may make a more permanent administration inevitable.

Peter Gambles 